\title{
Resiliens i et globalt klimaperspektiv
}

AF MIKKEL FUGL ESKJÆR

SLAGMARK \#72

SIDER: $65-80$

\section{RESILIENS OG KLIMAPROBLEMATIKKEN}

At resiliens er kommet til at stå centralt i klimadiskussionen er næppe overraskende, al den stund begrebet handler om systemers evne til at absorbere forstyrrelser og usikkerhed gennem selvorganisering og selvfornyelse (Folke, 2006). Klimaforandringer vil i stigende grad forstyrre socio-økologiske systemers balance og identitet, hvilket kalder på såkaldte "bounce-back" mekanismer, strukturtilpasninger og systembevarende foranstaltninger. Inden for klimaområdet anvendes resiliensbegrebet imidlertid i forskellige sammenhænge og tjener forskellige funktioner. Med fare for forenkling kan man skelne mellem en akademisk og en praktisk tilgang til begrebet, skønt det skal understreges, at de to områder naturligvis leverer input til hinanden. Resiliens optræder dels i anvendelsesorienteret forskning og opfanges ligeledes (i et vist omfang) af embedsværk og civilsamfund. I den forstand er der tale om en analytisk distinktion, der primært tjener til at indfange de diskursive spændinger som følger af begrebets popularitet i den globale klimadiskurs.

Den akademiske tilgang beskæftiger sig med resiliensbegrebets genealogi, udbredelse, indhold og implikationer (Nelson, 2011; Walker \& Cooper, 2011), herunder forskelle og affiniteter med beslægtede begreber såsom tilpasning [adaptation] og sårbarhed [vulnerability]. F.eks. er resiliensbegrebet mere systemisk anlagt i sammenligning med adaptation-begrebet, som er overvejende handlingsbaseret. Oprindeligt var resiliensbegrebet ligeledes modelbaseret, dvs. søgte at simulere komplekse systemers selvopretholdelsesevne overfor potentielle forandringer, i modsætning til adaptationsbegrebet som bygger på komparative case studier af konkrete risikore- 
ducerende foranstaltninger (Janssen, Schoon, Ke, \& Börner, 2006; Nelson, Adger, \& Brown, 2007). På et teoretisk plan implicerer resiliensdiskussionen således klassiske videnskabsteoretiske dikotomier (f.eks. struktur/aktør) såvel som epistemologiske principper (f.eks. kvantitative/kvalitative tilgange, simulation/observation).

Den praktiske tilgang til resiliensbegrebet handler om at udforme nationale og internationale klimastrategier. Resiliensbegrebet tilbyder en kontekstsensitiv tilgang til klimatilpasning med afsæt i lokale ressourcer og med henblik på at udbygge sociale systemers kapacitet til at absorbere og lære af chokpåvirkninger. I nationale og internationale fora anlægges til tider en pragmatisk tilgang til de principielle forskelle og ligheder med beslægtede begreber. Som eksempel kan nævnes IPCC's definition af resiliens, som forener elementer af (øjeblikkelig) sårbarhedsreduktion med principperne bag (langsigtet) modstandsdygtighed:

Evnen ved et system og dets delementer til at anticipere, absorbere, akkommodere og komme sig fra følgerne af farlige begivenheder på betimelig og effektiv vis, inklusiv ved at sikre bevarelse, genskabelse og forbedring af dets essentielle strukturer og funktioner. (citeret i World Bank, 2013, s. 4)

Første del af denne bestemmelse lægger sig tæt op af IPCC’s egne definition af sårbarhed med fokus på umiddelbar katastrofehåndtering (se Janssen m.fl., 2006, s. 241), hvorimod sidste del minder mere om resiliensbegrebets systembevarende dimension. Det illustrer imidlertid blot, at begrebet i en praktisk sammenhæng primært tjener til at skabe funktionel klimatilpasning på lokalt, nationalt og overnationalt niveau.

Nærværende artikel beskæftiger sig med den praktiske tilgang til resiliensbegrebet. Hensigten er at undersøge resiliensbegrebet $\mathrm{i}$ lyset af globale klimaforandringer og med særligt fokus på det Globale Syd. Baggrunden er det velkendte forhold, at den fattige del af verden i store træk kommer til at betale prisen for den rige verdens historiske kulstofudledning:

Klimaforandring vil få størst indvirkning på den fattigste og mest marginaliserede befolkning, som ofte lever i høj-risiko områder [...] Indvirkningen af klimaforandringer på fattigdom forventes at være regressiv og forskellig, med størst effekt på den fattige bybefolkning [...] og stærkt sårbare lande [...] Mange af disse lande har samtidig mindst kapacitet til at forberede og absorbere følgerne af klimabegivenheder. (World Bank, 2013, s. viii) 
Artiklen former sig som begrebslige nedslag og diskussioner af resiliensbegrebets rolle og funktion i et globalt klimaperspektiv. Målet er at afdække de områder, hvor resiliensbegrebet optræder i den internationale klimadiskurs, samt at udpege begrebets strategiske og diskursive funktioner. Håbet er, at det kan tjene til både at forklare og problematisere begrebets nuværende popularitet. Fire aspekter vil blive berørt. For det første klargøres resiliensbegrebets forankring i det internationale klimaregime, fremfor alt i relation til distinktionen mellem mitigation og adaptation. For det andet undersøges resiliens som en genbeskrivelse af eksisterende socio-økologiske forsvarsmekanismer. For det tredje overvejes resiliens som et eksempel på stigende sammentænkning af klimatilpasning og udviklingshjælp. Endelig vurderes resiliens som en strategisk ressource i kampen om klimafinansiering. De fire nedslag er ikke udtømmende for spørgsmålet om resiliens i den globale klimadiskurs, men tilbyder et blik på de dynamikker, som ligger bag begrebets optræden i både klimapolitiske, udviklingspolitiske og klimafinansielle sammenhænge.

\section{RESILIENS OG DET GLOBALE SYD: BANGLADESH SOM EKSEMPEL}

Som eksempel på resiliensbegrebets placering i klimadiskussionen vedrørende det globale syd trækker artiklen på data og eksempler fra Bangladesh. Det er der flere grunde til:

(1) For det første er Bangladesh gentagne gange blevet udpeget som verdens mest klimaudsatte nation pga. en sårbar kombination af høj fattigdom, overbefolkning og en særlig udsathed overfor ekstreme vejrfænomener (Maplecroft, 2014). Som lavtliggende kystland rammes Bangladesh ofte af tropiske cykloner fra den Bengalske bugt. Dertil kommer, at Bangladesh omfatter verdens næststørste floddelta, bestående af Ganges, Brahmaputra og Meghna som løber sammen og udmunder i den Bengalske Bugt, hvorfor landet ofte udsættes for oversvømmelser. Begge forhold vil forværres i takt med globale klimaforandringer. Dels pga. et øget omfang af voldsomme cykloner i den Bengalske bugt og den medfølgende stigning i risikoen for oversvømmelse og saltindtrængning i den sydlige del af landet. Dels pga. tiltagende afsmeltning fra Himalaya, hvorfra alle tre floder i det bengalske floddelta udspringer.

Den største trussel stammer dog fra stigende vandstand i den Bengalske Bugt. De mere dystre klimascenarier forudsiger at: "havstigning vil [...] oversvømme 18 
procent af Bangladesh" (World Bank, 2010, s. 28). I en af verdens tættest befolkede nationer, med en befolkning på ca. 160 millioner, vil et tab af små $20 \%$ af landmassen være katastrofal. Allerede i dag taler man om klimamigration inden for Bangladesh' grænser, når befolkningsgrupper fraflytter lavtliggende områder pga. oversvømmelser eller saltvands-indtrængen (MoEF, 2009).

(2) Bangladesh har længe optrådt som arketypisk udviklingsland og et udviklingspolitisk laboratorium. Landet er blevet kaldt en "test case for udvikling” ud fra devisen at: "Hvis udvikling kan lykkes i Bangladesh, er der ringe tvivl om, at det kan lykkes hvor som helst” (Faaland \& Parkinson, 1976, s. 747). I dag udgør Bangladesh i stigende grad et laboratorium for globale klimaudfordringer (Inman, 2009), og indtager rollen som en slags "klimaforandrings-hot spot" (Raihan, Huq, Alsted, \& Andreasen, 2010, s. 9).

(3) Trods disse vanskelige forhold og forudsætninger fremstår Bangladesh ikke desto mindre som et udviklingsland på forkant med den klimapolitiske dagsorden. Landet var blandt de første udviklingslande til at udforme en såkaldt NAPCC ( $\mathrm{Na}$ tional Action Plan on Climate Change), ligesom landet har indtaget positionen som talsmand for de mindst udviklede lande (Least Developed Countries) i internationale klimaforhandlinger.

I det lys tjener Bangladesh som håndgribelig case, der kan anskueliggøre resiliensbegrebets betydning og implikationer i et globalt klimaperspektiv. Bangladesh udgør dog i et vist omfang dét, som i metodologiske termer kaldes en "kritisk" case i modsætning til f.eks. en typisk case. Eftersom Bangladesh er blandt verdens mest klimasårbare nationer, får resiliensbegrebet ofte en drejning i retning af risikoog katastrofehåndtering. På dette punkt minder Bangladesh om de såkaldte Små Østater og andre tropiske deltaområder (Joerin, Shaw, Takeuchi, \& Krishnamurthy, 2012). Det påvirker selvsagt casens ekstrapolationskraft i forhold til mindre udsatte nationer, hvor resiliensbegrebet bevarer mere af sit langtids- og systembevarende aspekt. Omvendt er styrken ved en kritisk case, at det sætter et begreb som resiliens på spidsen og tydeliggør de diskursive forskydninger som følger af begrebets migration til nye domæner. 


\section{RESILIENS OG KLIMATILPASNING}

En vigtig kilde til forståelse af resiliensbegrebets status og betydning skal findes i det internationale klimaregime og begrebsparret mitigation og adaptation. Siden den såkaldte "Bali køreplan" op til COP15 i København i 2009, har der eksisteret en slags international arbejdsdeling mellem Nord og Syd, dvs. mellem industrialiserede lande og udviklingslande. Den består grundlæggende $i$, at de rige lande påtager sig deres historiske ansvar for udledningen af drivhusgasser ved at mindske [mitigate] kilderne til global opvarmning. Derimod kan udviklingslande koncentrere sig om at tilpasse sig følgerne af kommende klimaforandringer. Udviklingslandene er dermed ikke forpligtede til CO2 reduktion, skønt de kan have en egeninteresse i at fremme grøn vækst. Fattigdomsbekæmpelse og udvikling har fortsat forrang, hvilket bl.a. Bangladesh gør helt klart: "Udvikling og fattigdomsudryddelse er landets prioritet. Landet afviser enhver handlig som vil bringe opnåelse af sikker adgang til mad, vand, energi og levebrød i fare” (MoEF, 2009, \$ 6).

Denne arbejdsdeling er naturligvis blevet kompliceret af vækstøkonomier som Indien og Kina, hvis historiske CO2 udledning stadig er begrænset, men hvis nuværende udledning efterhånden overgår den rige verdens. Arbejdsdelingen kompliceres yderligere af, at de to begreber i det lange løb ikke kan isoleres: "Færre udgifter til reduktion [mitigation] vil betyde større udgifter til tilpasning [adaptation]" (World Bank, 2010, s. 7). Dertil kommer, at alle nationer, både rige og fattige, i fremtiden må indstille sig på klimatilpasning.

Ikke desto mindre angiver distinktionen to forskellige tilgange til klimaproblematikken. Den første handler om mitigation og promoveres ofte i relation til forestillinger om "smart" klimapolitik (World Bank, 2010) og grøn energiomstilling. Tilgangen er funderet i moderate miljødiskurser om bæredygtig udvikling og økologisk modernisering (Fishcer \& Freudenburg, 2001), som fastholder et økonomisk vækstprincip, i modsætning til f.eks. dybdeøkologien (Drengson \& Inoue, 1995) eller mere radikale miljødiskurser om nulvækst (Dryzek, 2005).

Den anden tilgang (adaptation) handler om at klimasikre nuværende og kommende udvikling, således at infrastrukturel systemudbygning ikke spoleres eller sættes i stå af fremtidige klimaforandringer. Det er denne tilgang, som mindst udviklede lande orienterer sig mod. Problemet er blot, at de to tilgange ikke har opnået samme opmærksomhed: "Der har allerede fundet en anselig analytisk indsats sted 
angående klimavenlig udvikling i form af reduktion af drivhusgasser [...] [Spørgsmålet om] hvordan udvikling kan gøres mere modstandsdygtig overfor følgerne af klimaforandringer har fået meget mindre opmærksomhed" (OECD, 2005, s. 15). Dertil kommer, at de rige landes reduktionsindsats på den korte bane vil have ingen eller næsten ingen positiv effekt for fattige lande pga. allerede ophobede drivhusgasser i atmosfæren: "En øjeblikkelig reduktion af drivhusgasser vil kun have signifikant indvirkning på fattigdom på den anden side af 2100 [...] hvilket understreger det påtrængende behov for at implementere resiliens- eller tilpasningsforanstaltninger, som er målrettet de fattige" (World Bank, 2013, s. 9).

Det er i forbindelse med behovet for klimatilpasning at resiliensbegrebet kommer ind i billedet, hvor det i stigende grad har erstattet fokus på bæredygtighed (Zolli, 2012). Bæredygtighed implicerer forestillingen om at opretholde en oprindelig ligevægtstilstand, hvorimod resiliens mere handler om at indarbejde omverdensforandringer. Tilpasning [adaptation] er således på flere områder blevet synonymt med resiliens (Nelson m.fl., 2007), dvs. bestræbelsen på at gøre både sociale og økologisk systemer modstandsdygtig overfor de stresspåvirkninger, som et forandret klima medfører. Det kan være umiddelbare foranstaltninger som at opføre stormly og udbygge varslingssystemer, eller mere langsigtede strategier som at afstå fra at fælde mangroveskov som beskytter mod oversvømmelse, eller at skifte til afgrøder som tolererer et højere saltindhold.

Bangladesh' officielle klimapolitik illustrerer tankegangen:

Målet for Bangladesh' klimaforandringsstrategi er at øge landets resiliens overfor klimaforandring; reducere og/eller eliminere de risici som klimaforandring udgør for national udvikling; og at skabe hurtig udvikling baseret på kulstoffattig vækst. Landet er fast overbevist om, at hurtig udvikling er den mest effektive vej til fattigdomsudryddelse og til at opbygge resiliens overfor klimaforandring.

(MoEF, 2009, § 43)

Dette tekstuddrag peger på to forhold; at tilpasning til klimaforandringer er blevet uadskilleligt fra spørgsmålet om resiliens. Men også at opbygning af denne modstandsdygtighed næppe kan skelnes fra mere traditionel udvikling.

Det attraktive ved resiliensbegrebet er således, at det ikke blot handler om at udvikle nye tilpasningsteknologier, men om at styrke og udbygge eksisterende ressourcer. Set fra et donorperspektiv gør det klimatiltag mindre omkostningsfulde, 
mens det fra et modtagerperspektiv tilfører bistandsområdet nye (klima)midler. Der er i begge tilfælde tale om en slags omfunktionering af udviklingshjælp og klimabistand, blot med omvendt fortegn; De rige lande redefinerer udviklingsmidler som klimabistand, og de fattige lande anvender klimamidler til udvikling.

\section{NYT ELLER GAMMELT? RESILIENS SOM GENBESKRIVELSE}

Vi må først spørge om hvorvidt resiliens dækker over noget nyt og i givet fald hvori dette består. Hverken cykloner eller oversvømmelser er nye fænomener i det Nordøstlige hjørne af det Indiske subkontinent. Tværtimod har naturkræfterne altid været en "protagonist" i regionens historie (Schendel, 2009, s. 9), hvor befolkningen har lært at leve med oversvømmelser, floderosion og andre voldsomme naturfænomener. Historisk set har disse klimatiske og geografiske forhold gjort Bengalen til et rigt og frugtbart område, eftersom oversvømmelser og aflejringer fra Himalaya har tilført området næring og tilladt intensiv landbrugsproduktion. Denne rigdom og overflod afspejler sig både i mytologien og historien. I tidlig kristen forestillingsverden blev Ganges forbundet med indgangen til Paradis (Darian, 2001); de første opdagelsesrejsende priste områdes pragt og rigdom (Schendel, 2009, s. 42-45); og under kolonialisme udgjorde Bengalen en hjørnesten i det britiske East India Company, hvor det i 1750 stod for omkring $75 \%$ af selskabets indiske handel (Lewis, 2011, s. 46).

Det er denne socio-økologiske rigdom og sociale resiliens som stresses i forbindelse med klimaforandringer, idet floderosion og saltvandsindtrængning ødelægger landbrugsproduktion og levevilkår. Imidlertid er pres på naturlige ressourcer hverken nyt eller ukendt. Tidligere er områdets resiliens blevet undermineret af andre menneskabte forandringer. Under kolonialismen foregik der en tvungen overgang fra selvforsynende landbrug til "cash crop"-økonomi, dvs. landbrugsproduktion med internationalt salg for øje, hvilket ikke blot gjorde Bengalen afhængig af verdensmarkedspriser, men også sårbar overfor fejlslagen høst og deraf følgende hungersnød (Schendel, 2009, s. 63). Senere er det særligt problemer med overbefolkning, som har stækket regionens modstandsdygtighed. Arven fra disse tidligere anslag mod regionens resiliens forstærkes blot i forbindelse med klimaproblematikken.

Flere af de tiltag som i dag forbindes med klimaresiliens har en lang forhistorie. F.eks. fremhæves Bangladesh ofte i både udviklings- og klimarapporter for udvik- 
lingen af tidlige varslingssystemer mod cykloner og oversvømmelser (IPCC, 2012, s. 308; World Bank, 2010, s. 105). Men disse systemer er ikke i første omgang reaktioner på klimaforandringer, skønt klimaproblematikken har skabt international fokus herpå. Landets morbide statistik på området illustrerer pointen. I 1970 ramtes Bangladesh af verdens hidtil mest dødelige cyklon. Et sted mellem 325.000 og en halv million mennesker omkom som følge af cyklon Bohla (MoEF, 2009, s. 11; Schendel, 2009, s. 124). De daværende Vestpakistanske myndigheders manglende indsats for at hjælpe deres landsmænd i Østpakistan blev en medvirkende årsag til Bangladesh' uafhængighedskamp i 1971 (Bass, 2013, kap. 2). I 1991 blev Bangladesh offer for endnu en af de mest dødelige cykloner med omkring 140.000 omkomne og 10 millioner hjemløse. Det er på den baggrund, at Bangladesh siden uafhængigheden har arbejdet med at udvikle varslingssystemer samt udbygge et netværk af cyklon-sheltere.

Da cyklonen Sidr ramte Bangladesh i 2007, var antallet af omkomne et sted mellem 3500 og 10.000. I 2013 var antallet reduceret til 13, da en tropisk storm ramte landet, skønt 8 millioner mennesker var i farezonen. UNDP skønner at: “Over 88 millioner mennesker som bor i lavtliggende flodsletter har nu yderligere to dages forberedelsestid inden forestående oversvømmelser; 112 millioner er i stand til at modtage og tilgå tidlig varslings- og katastroferelateret information" (UNDP, 2014, s. 8). Disse chokabsorberende ressourcer bliver i stigende grad fremhævet og genfortolket i lyset af klimaforandringer. Hvad der før handlede om tilpasning og handlingsberedskab i forbindelse med naturkræfter handler nu om modstandsdygtighed i forhold til menneskeskabte klimaforandringer. Sat lidt på spidsen kunne man sige, at vi er gået fra en antropologisk (jf. Jansen et al 2006 s. 241) til en antropocœn problemstilling. Sidstnævnte begreb henviser til, at vi befinder os i en periode af jordens historie, hvor summen af menneskelige aktiviteter er begyndt at påvirke planetens samlede økosystem (Crutzen \& Stoermer, 2012). Resiliens går derfor fra at betyde modstandsdygtighed overfor udefrakommende kræfter til at betyde selvregulering i forhold til selvskabte forandringer.

Det viser imidlertid også, at begrebet om resiliens næppe kan adskilles fra mere essentielle spørgsmål om udvikling. Som klimarapporter påpeger gang på gang, så er økonomisk udvikling det bedste værn mod klimaforandringer: "Tilpasning til klimaforandring [...] handler grundlæggende om udvikling” (Raihan m.fl., 2010, s. 24). Tendensen afspejler sig ligeledes i FN's nyligt vedtagne Bæredygtige 
Udviklingsmål, hvor klima- og udviklingsmål i stort omfang er smeltet sammen og hvor delmål 13,1 specifikt handler om at: "Styrke resiliens og adaptiv kapacitet til klimarelaterede farer og naturkatastrofer" (UN Sustainable Development, 2015).

\section{RESILIENS = KLIMATILPASNING + UDVIKLING}

Forstået som henholdsvis systemtilpasning og systemudbygning er resiliens og udvikling ikke forbeholdt udviklingslande, men angår ligeledes industrialiserede lande. Imidlertid dækker det over temmelig forskellige forhold. I den rige verden handler udvikling typisk om grøn omstilling og alternativer til vores "high carbon lives" (Urry, 2011). Målet er at opnå bæredygtig udvikling defineret som: "udvikling som imødekommer samtidens behov uden at kompromittere fremtidige generations evne til at opfylde egne behov" (World Bank, 2010, s. 39). Resiliens betyder i den forbindelse sikring af infrastruktur som transport og elektricitet så det ikke påvirkes af ekstremvejr, eller udvikling af bymiljøer så de ikke påvirkes negativt af skybrud eller stigende temperaturer.

I udviklingslande handler udvikling derimod om fattigdomsbekæmpelse, at overvinde underernæring og smitsomme sygdomme samt at opbygge infrastruktur i form af vejnet og adgang til elektricitet. Resiliens henviser til fundamentale fornødenheder som tag over hovedet, fødevaresikkerhed, adgang til beskyttelsesrum, et vejnet så man kan komme væk fra varslingsområder, rent vand og lægehjælp, når katastrofen indtræffer mm.

Udfordringen er i den forbindelse, at klimaforandringer risikerer at underminere de fremskridt som har fundet sted, f.eks. i forbindelse med opfyldelsen af FN's 2015 mål (GED, 2013; UN MDG, u.å.): "Udviklingslande vil bære størstedelen af byrden ved klimaforandringer, selv mens de kæmper for at overkomme fattigdom og fremme økonomisk vækst. For disse lande truer klimaforandring med at øge sårbarhed, erodere hårdt tilkæmpede fremskridt, og alvorligt underminere udsigterne til udvikling" (World Bank, 2010, s. xiii). Det er på den baggrund, at udvikling og klimahjælp i stigende grad sammentænkes og betragtes som to sider af samme sag. Det giver ingen mening at iværksætte bistandsprogrammer såsom udvikling af infrastrukturprojekter, hvis disse skylles i havet eller borteroderes om føje år: "Følgerne er, at udvikling må gøres anderledes med langt større vægt på risici fra vejr 
og klima” (World Bank, 2010, s. 12). Man har derfor i en årrække talt om at mainstreame, dvs. indarbejde klimatilpasning i udviklingsplanlægning (Pervin, 2013).

Denne nødvendige kombination af klima- og udviklingsbistand er imidlertid langt fra uproblematisk. Et tidligt casestudie fra Verdensbanken har påpeget en række problemstillinger (OECD, 2005). For det første forfølger udvikling og klimatilpasning ikke nødvendigvis samme mål. Udvikling handler i første omgang om basal fattigdomsbekæmpelse, hvorimod klimatilpasning søger at opbygge langsigtet resiliens. Til tider kan det ene stå i vejen for det andet. Rydder man mangroveskov eller bjergskråninger til landbrugsproduktion øges risikoen for oversvømmelse og jorderosion - eksempler hvor udvikling fører til det modsatte af resiliens.

Udvikling og klimatilpasning opererer således ofte på forskellige tidsskalaer, hvilket illustrerer de skaleringsdynamikker som er en indbygget del af klimaproblematikken (Eskjær \& Sørensen, 2014, s. 15), og som er et centralt omdrejningspunkt for resiliensbegrebet (Folke, 2006). Udvikling arbejder ofte ud fra et her-og-nu perspektiv, der handler om at hindre strukturelle konsekvenser af sult, underernæring, økonomisk misvækst mm. Klimatilpasning arbejder derimod med langtidsprognosticeringer, der handler om at gøre lokalbefolkninger resiliente overfor fremtidige klimachok.

Resiliens betyder i den forbindelse at tage udgangspunkt i lokalbefolkningens egne ressourcer: "en afgørende ressource i katastrofeforberedelse er folk selv" (UNDP, 2014, s. 44). F.eks. skaber cyklon-sheltere ikke i sig selv resiliens, hvis den fattigste del af befolkningen ikke bruger dem af frygt for at miste deres få ejendele: "Hvis jeg søger tilflugt i et cyklon-shelter og overlever blot for at komme tilbage og finde ud af, at jeg intet har tilbage, kan jeg lige så godt dø, da jeg intet har at leve af” (Raihan m.fl., 2010, s. 30). Resiliens handler således om at forstå klimatilpasning ud fra akutte og kontekstspecifikke forudsætninger, hvilket i dette tilfælde vil sige også at beskytte de allerfattigstes få besiddelser. I mere tekniske termer forener resiliens således forskellige tidsskaler som griber ind i hinanden; det handler om at overleve både under og efter katastrofen, samt at kunne modstå næste katastrofe.

Det attraktive ved resiliensbegrebet er, at det tager afsæt i eksisterende strukturer og lokale tilpasningskapaciteter og dermed rummer løftet om at overkomme de udfordringer som foreningen af klimatilpasning og udvikling rejser. Det er således symptomatisk, at resiliens i de senere år synes at erstatte adaptationsbegrebet. Der tales i stigende grad om: "inkorporeringen af klima- og katastrofere- 
siliens i bredere udviklingsprocesser" og at "opbygning af klimaresiliens [...] bør være højt prioriteret [front and center] på udviklingsdagsordenen” (World Bank, 2013, s. vi, v).

Dermed ikke sagt at resiliensbegrebet løser problemerne omkring integration af klimatilpasning og udvikling. Men det repræsenterer muligvis en erkendelse af nogle af de komplekse sammenhænge og skalaproblemer, som knytter sig til sammentænkningen af klima og udvikling. I Bangladesh' tilfælde handler det om at:

[n]ationale planlægningsprocesser nu inkluderer kobling mellem fattigdom, klimaforandring og katastrofe [...] Dette inkluderer mål for forberedelse, tilsyn og monitorering af investeringer ved brug af et sæt indikationer, som sporer i hvilket omfang planerne er fattigdomsorienteret [propoor], miljøvenlige, lav-emissions og klimaresiliente (UNDP, 2014, s. 45).

\section{RESILIENS OG KLIMAFINANSIERING}

Ovenstående citat rummer en vigtig dimension, nemlig spørgsmålet om finansiering af klimatiltag, understreget ved behovet for: "forberedelse, tilsyn og monitorering" af klimainvesteringer. For udviklingslande kan klimatilpasning ikke adskilles fra spørgsmålet om klimafinansiering. Siden forhandlingsvanskelighederne ved COP15 i København, er spørgsmålet om klimafinansiering og kompensation for "tab og skader" [loss and damage] blevet centrale mekanismer til at få rige og fattige lande til at mødes om en bindende klimaaftale. Loss and damage angår de tab, som vi allerede ved ikke kan undgås vha. udledningsreduktion [mitigation], og som fattige udviklingslande ikke har ressourcer til at gardere sig imod [adaptation]: "loss and damage [...] søger at gå ud over tilpasning for at adressere tiloversværende [residual] katastrofepåvirkning i de fattigste og mest sårbare lande, som er påvirket af klimaforandring" (World Bank, 2013, s. 1).

I flere omgange er de fattige landet blevet lovet store økonomiske midler til "loss and damage", skønt virkeligheden sjældent lever op til skåltalerne. Dog synes en international ordning omkring the Green Climate Fond at have taget form. Som goodwill-skabende optakt til COP21 frigav fonden således de første midler til en række udviklingslande, herunder Bangladesh (GCF, 2015), ligesom "loss and damage"-princippet er blevet indskrevet i den nylige Parisaftale fra COP21 (UNFCCC, 2015, artikel 8) 
Det er ikke mindst i relation til spørgsmål om klimafinansiering, at resiliensbegrebet for alvor bliver sat i relief. Her tydeliggøres det nemlig, hvorvidt tilpasningsstrategier finansieres som sårbarhedsreduktion og risikohåndtering eller længerevarende systemiske tilpasninger. Et eksempel på sidstnævnte vil være at undgå klimamigration og "displacement": "At flygte fra klima hot spots er ikke en 'tilpasningsstrategi', det er et forsøg på 'overlevelse' [...] inden for rammerne af en 'tilpasningsfiasko"' (Shamsuddoha, 2015, s. 9). I den sammenhæng betyder resiliens at forhindre klimaudsatte befolkningsgrupper i at migrere til storbyernes slumkvarterer som følge af jorderosion, saltvandsindtrængning eller ødelagt fiskeri, og i stedet sikre nye eksistensgrundlag for en klimapåvirket lokalebefolkning, f.eks. gennem uddannelse og ændrede økonomiske aktiviteter. Sådanne kapacitetsopbyggende foranstaltninger er imidlertid tids- og ressourcekrævende, og har dårlige forudsætninger inden for bistandssystemer og udviklingsprogrammer, der løber over korte årrækker og tildeles inden for politisk bestemte tidshorisonter.

I den forbindelse bliver resiliens en vigtig strategisk ressource. Hvis lande kan dokumentere, at klimatilpasningsprojekter er resiliente, og hvis der iværksættes mekanismer til at monitorere en sådan resiliens, bliver det alt andet lige lettere at opnå støtte fra grønne klimafonde og tiltrække grønne klimainvesteringer. Et land som Bangladesh, der allerede bruger betydelige midler på klimatilpasning (UNEP, 2014), er yderst opmærksomt på betydningen af sådanne monitoreringsredskaber (Huq, 2014a): "grønne klimafonde [...] udgør umiddelbare muligheder for landet, men regeringen må bevise dets evne, transparens og ansvarlighed [accountability] for at tilgå de globale fonde" (Rahman, 2016). Endnu er der dog tale om et område præget af usikkerhed: "tilpasning til klimaforandring er et nyt fænomen, og der er endnu ikke klare retningslinjer for, hvad der fungerer" (Huq, 2014b). At klimatilpasning i stigende grad forventes at være resilient og kapacitetsopbyggende kan dog læses som udtryk for en sådan tentativ retningslinje for fremtidig klimabistand.

\section{DISKUSSION}

Nærværende fremstilling har belyst resiliensbegrebet i et klimatilpasnings- og udviklingsperspektiv. Gennemgangen har vist, at klimaproblematikkens alvor og kompleksitet har fremtvunget en nødvendig sammentænkning af begreber med overlappende betydninger og domæner, såsom sårbarhed, katastrofehåndtering, 
tilpasning og resiliens. Dermed tilskrives resiliensbegrebet imidlertid varierende betydninger og funktioner i forskellige klimapolitiske arenaer, med deraf følgende risiko for at begrebernes principielle forskelle og nuancer fortoner sig, en risiko der ikke mindst gælder resiliensbegrebet.

I udviklingspolitiske sammenhænge er resiliens blevet nærmest allestedsnærværende inden for en vifte af udviklingsmål: "styringsprocesser [governance], samfund, lokalsamfund og økosystemer må blive resiliente for at absorbere chok og indstille sig på en mere bæredygtig verden” (Rahman, 2016). I ovenstående citat er begrebet gået fra at angive en forholdsvis teknisk forståelse af komplekse systemers bounce-back-kapacitet i forbindelse med ydre stresspåvirkning til at blive et tomt mål for simultane processer. Dermed bliver det uklart, hvad modstandsmekanismer dækker over, hvordan de fungerer og hvordan de kan implementeres. Denne begrebsudbredelse har givet anledning til kritiske analyser af resiliensbegrebet som et nyt "omsiggribende idiom for global governance", hvor "opbygning af resiliens" fremstilles som nødvendig foranstaltning overfor tilsyneladende uundgåelige kriser (klimatiske, økonomiske, politiske), hvilket naturligvis er en ideologisk maskering af at andre løsningsmodeller og udviklingstendenser er mulige (Walker \& Cooper, 2011).

I en praktisk sammenhæng dækker resiliens således over flere mekanismer og dynamikker, som hverken er entydige eller modsætningsfrie. Det peger på, at der foregår en løbende diskursiv kamp om begrebets omfang og implikationer, f.eks. mellem en eksklusiv eller inklusiv definition, eller mellem en teoretisk og praktisk begrebsanvendelse. Det er denne flertydighed, som gør begrebet dynamisk og muligvis forklarer dets popularitet i diverse klimadiskurser. Begrebets potentiale er dets kontekstspecifikke tilgang samt løftet om at gøre klimatilpasning modstandsdygtig, udviklingsorienteret og fattigdomsorienteret. Begrebets svaghed er imidlertid, at det risikerer at tildække de principielle forskelle mellem udvikling og klimatilpasning, at det legitimerer et dræn fra udviklingsmidler til klimabistand, at det erstatter langsigtede systemindgreb med korttidsløsninger eller at det reduceres til en strategisk ressource snarere end et redskab til rent faktisk at skabe tilpasnings- og modstandsdygtige systemer. 


\section{LITTERATUR}

Bass, G. J. (2013). The Blood telegram: Nixon, Kissinger, and a forgotten genocide (første udgave). New York: Alfred A Knopf.

Crutzen, P. J., \& Stoermer, E. F. (2012). The “Anthropocene". Global Change Newsletter, Volume (41), 17-18.

Darian, S. G. (2001). Ganges in Myth and History. Delhi: Motilal Banarsidass Publ.

Drengson, A. R., \& Inoue, Y. (Red.). (1995). The deep ecology movement: an introductory anthology. Berkeley, Ca.: North Atlantic Books.

Dryzek, J. S. (2005). The Politics of the Earth. Environmental Discourses. Oxford: Oxford University Press.

Eskjær, M. F., \& Sørensen, M. (2014). Introduktion. Humanistisk Klimaforskning. i M. Sørensen \& M. F. Eskjær (Red.), Kilma og mennesker. Humanistiske perspektiver på klimaforandringer (s. 11-26). København: Museum Tusculanum.

Fishcer, D. R., \& Freudenburg, W. R. (2001). Ecological Modernization and Its Critics: Assessing the Past and Looking Toward the Future. Society and Natural Resources, 14, 701-709.

Folke, C. (2006). Resilience: The emergence of a perspective for social-ecological systems analyses. Global Environmental Change, 16 (3), 253-267. http://doi.org/10.1016/j.gloenvcha.2006.04.002

Faaland, J., \& Parkinson, J. R. (1976). Bangladesh: Gradual Development or Deepening Misery? World Development, 4(9), 739-747.

GCF. (2015, november 6). DECISION B.11/11 Agenda item 11: Consideration of funding proposals. Green Climate Fund. Hentet fra www.greenclimate.fund/documents/20182/76153/ DECISION_B.11_11_-_Consideration_of_funding_proposals.pdf/92c5d2f0-520e-4f74-a2e5badb7ea54a68?version $=1.0$

GED. (2013). The Millennium Development Goals Bangladesh Progress Report 2012 (s. 160). Dhaka: General Economics Division (GED) Bangladesh Planning Commission Government of the People's Republic of Bangladesh.

Huq, S. (2014a). Changing the narrative on Bangladesh and climate change. The Daily Star. Dhaka. Hentet fra www.thedailystar.net/changing-the-narrative-on-bangladesh-and-climatechange- 31792

Huq, S. (2014b). Tackling climate change effectively. The Daily Star. Dhaka. Hentet fra www.thedailystar.net/tackling-climate-change-effectively-11070

Inman, M. (2009). Where warming hits hard. Nature Reports Climate Change, (0902), 18-21. http://doi.org/10.1038/climate.2009.3 
IPCC. (2012). Managing the risks of extreme events and disasters to advance climate change adaption: special report of the Intergovernmental Panel on Climate Change. (C. B. Field, Red.). New York, NY: Cambridge University Press.

Janssen, M. A., Schoon, M. L., Ke, W., \& Börner, K. (2006). Scholarly networks on resilience, vulnerability and adaptation within the human dimensions of global environmental change. Global Environmental Change, 16(3), 240-252. http://doi.org/10.1016/j.gloenvcha.2006.04.001

Joerin, J., Shaw, R., Takeuchi, Y., \& Krishnamurthy, R. (2012). Assessing community resilience to climate-related disasters in Chennai, India. International Journal of Disaster Risk Reduction, 1 , 44-54. http://doi.org/10.1016/j.ijdrr.2012.05.006

Lewis, D. (2011). Bangladesh. Politics, Economy and Civil Society. Cambridge: Cambridge University Press.

Maplecroft. (2014). Climate Change and Environmental Risk Atlas 2015. Maplecroft. Hentet fra http://maplecroft.com/portfolio/new-analysis/2014/10/29/climate-change-and-lack-food-security-multiply-risks-conflict-and-civil-unrest-32-countries-maplecroft/

MoEF. (2009). Bangladesh Climate Change Strategy and Action Plan 2009 (s. xviii + 76pp.). Ministry of Environment and Forests, Government of Bangladesh.

Nelson, D. R. (2011). Adaptation and resilience: responding to a changing climate. Wiley Interdisciplinary Reviews: Climate Change, 2(1), 113-120. http://.doi.org/10.1002/wcc.91

Nelson, D. R., Adger, W. N., \& Brown, K. (2007). Adaptation to Environmental Change: Contributions of a Resilience Framework. Annual Review of Environment and Resources, 32(1), 395-419. http://.doi.org/10.1146/annurev.energy.32.051807.090348

OECD. (2005). Bridge over troubled waters: linking climate change and development. (S. Agrawala \& A. U. Ahmed, Red.). Paris: Organisation for Economic Co-operation and Development.

Pervin, M. (2013). Mainstreaming climate change resilience into development planning in Bangladesh (s. 12). Dhaka: iied; UNEP; UNDP.

Rahman, A. A. (2016). Inclusive growth and climate resilient development. The Daily Star, april 2, s. 4, 9. Dhaka.

Raihan, M. S., Huq, M. J., Alsted, N. G., \& Andreasen, M. H. (2010). Understanding climate change from below, addressing barriers from above: Practical experience and learning from a communitybased adaption project in Bangladesh (s. 98). Dhaka: ActionAid Bangladesh.

Schendel, W. van. (2009). A History of Bangladesh. Cambridge: Cambridge University Press.

Shamsuddoha, M. (2015). Climate-Induced Displacemanet and Migration: Policy Gaps and Policy Alternative (s. 12). Dhaka: CPRD. 
UNDP. (2014). Resilient Bangladesh. UNDP Bangladesh Annual Report 2013/2014 (s. 68). Dhaka: UNDP Bangladesh.

UNEP. (2014). Bangladesh Uncovers the Crippling Cost of Climate Change Adaptation. UNEP news center. Hentet fra www.unep.org/newscentre/default.aspx?DocumentID=2788\&ArticleI $\mathrm{D}=10864 \& \mathrm{l}=\mathrm{en}$

UNFCCC. (2015). Adoption of the Paris Agreement. UNFCCC.

UN MDG. (u.å.). Millennium Development Goals. Hentet fra www.un.org/millenniumgoals/

UN Sustainable Development. (2015). Sustainable development goals. Hentet fra https://sustainabledevelopment.un.org/topics/sustainabledevelopmentgoals

Urry, J. (2011). Climate Change \& Society. Cambridge: Polity.

Walker, J., \& Cooper, M. (2011). Genealogies of resilience: From systems ecology to the political economy of crisis adaptation. Security Dialogue, 42(2), 143-160. www.doi. org/10.1177/0967010611399616

World Bank. (2010). World Development Report 2010. Development and Climate Change. Washington DC: World Bank.

World Bank. (2013). Building Resilience. Integrating Climate and Disaster Risk into Development (s. 44). Washington DC: The World Bank.

Zolli, A. (2012, november 2). Learning to Bounce Back. New York Times. N.Y. Hentet fra www. nytimes.com/2012/11/03/opinion/forget-sustainability-its-about-resilience.html?_r=0 